\title{
DETERMINANTS OF ECONOMIC GROWTH IN THE EU NUTS2 REGIONS
}

\author{
ALEKSEJS SREBNIJS \\ MAKSIMS SIČS \\ OL,EGS KRASNOPJOROVS
}

\begin{abstract}
The authors employ a Bayesian Model Averaging (BMA) framework to study economic growth determinants of the 276 European regions during 20062015 period. This framework allows one to address, as much as possible to date, the model uncertainty problem. Application of BMA provides a possibility to run simultaneously numerous models to test each determinant in all possible variations. By controlling for top 500 higher education institutions over the world, the authors find statistical evidence that not only quantity of educational institutions does matter, but also the quality of each. In fact, it is one of the significant determinants of economic growth. Also, the model proves that higher education level, higher share of ICT patents, higher prime age population share, as well as higher manufacturing share are positively associated with subsequent economic growth; whereas, capital city regions tend to develop faster. The regions that tend to have a higher share of people with primary-only education have forecasted slower growth, as well as $\mathrm{CO}_{2}$ emissions and rapid population growth tend to have a negative correlation with economic growth. The findings suggest that a high share of information and communication technologies patents and a high share of industry in gross value added (GVA) will positively affect economic development. The authors also found a positive spillover effect from the neighbouring regions. Finally, the findings confirm a conditional convergence process among European regions - regions with higher initial income tend to develop slower if other factors remain unchanged.
\end{abstract}

Keywords: Economic growth, Bayesian Model Averaging (BMA), conditional convergence, European NUTS 2 regions

JEL code: $\mathrm{C} 11, \mathrm{O} 47, \mathrm{R} 11$

\section{INTRODUCTION}

Starting from the middle of the $20^{\text {th }}$ century, econometricians were using Standard Ordinary Least Squares to investigate which factors influence the economic growth. Extensive research was performed to explore new determinants, allowing regulators to correctly identify directions of reforms needed to be implemented to boost economic growth. Solow (1956) and Swan (1956) are pioneers who studied economic growth and conditional convergence, 
also known as catch-up effect theory'. This gave birth to a new stream of research called "Growth Econometrics". Solow and Swan invented neoclassical growth model showing that GDP per capita tends to converge over time. Subsequent authors identified that the study can be improved by determining what influences the productivity of labour and capital accumulation. Thus, such research papers as Barro (1991), Levine and Renelt (1992), Magrini (1998), Henderson and Russel (2004) added education attainment, the degree of macroeconomic stability, human capital, research activities, literacy rate, fertility rate, mortality rate, spillovers of technological knowledge and many other determinants to explain productivity of previously discussed factors.

Despite being exhaustively studied on a cross-country level, the economic growth in regions has been remaining an open question for several decades, because of data-sensitive results. Researchers found it essential to analyse regional growth since regulators generally implement structural reforms that affect regions and consequently by their means influence macroeconomic condition of the countries. Regional level studies allowed to identify more potential GDP per capita growth determinants, thus, allowed making better strategic decisions for regulators. Authors of regional studies analysed regional economic growth of a wide variety of countries: analysis of American regions by Deller S. C., Lledo V., Marcouiller D. W. (2008), study by Ding S., Knight J. (2008) of Chinese provinces, paper of Gonzalez \& Montolio (2004), who investigated growth determinants of Spanish regions, and study of European NUTS2 regions by Cuaresma J. C., Doppelhofer G. \& Feldkircher M. (2014). The authors build on a research study on European NUTS2 regions since conditional convergence in each geographical area has its specifics. The difference might occur due to region-specific economic, political or other factors. Due to the free-trade agreement, countries in European Union can trade without any barriers. Additionally, citizens of European countries can travel across the region without barriers. This might enhance the labour mobility across the countries and, consequently, might speed up the conditional convergence. A key difference between Europe and other world regions is a quite rapid change in the list of member countries. This can have an ambiguous effect on the conditional convergence. On the one hand, the geographic expansion of the EU might have a positive effect on conditional convergence due to additional funds received from the EU. On the other hand, additional costs to meet the requirements of European Union for joining the union and inefficient policies of EU might destroy the economic value. The effect is unclear and economic theory has poor evidence that would explain this. Moreover, the previous studies (for example, Cuaresma et al., 2009; Cuaresma et al., 2014) use pre-crisis data to find economic growth determinants. Importantly, pre-crisis economy was peaking, which might bias the impact of macroeconomic indicators on economic growth. For example, Latvian GDP per capita in 2008 was 11110 EUR, however, in 2009,

1 The theory states that regions with lower level of per capita income, controlling all the other factors, tend to grow at faster rates than richer regions. 
it was already 8704 EUR; total investments as \% of GDP have declined by $37.35 \%$ in 2009; etc. (International Monetary Fund, 2010).

Finally, the novelty of the article lies behind the explanation of the GDP growth per capita by the quality of education in a region. The authors measure the quality of education in a region by adding a variable that represents the number of universities in a region conditional upon inclusion in top 500 Shanghai Jiao Tong University Ranking in 2005. The authors believe that the better the quality of education that was recognised internationally the larger should be the GDP growth per capita of a region.

Up until now, numerous factors that explain economic growth have been identified, and researchers constantly continue to look for new determinants that are related to economic growth. However, more determinants also caused limitations for researchers and increased the uncertainty of the model. Linear regressions are sensitive to overfitting. When the model includes too many parameters, compared to the number of observations, the output of regression erodes because it starts to incorporate random error, i.e. noise; rather than just investigating the causal effect between the variables. Another problem that arises is the lack of methods through which computers would be able to aggregate the whole set of variables and provide reliable estimates of the marginal effects. One of the ways to mitigate the uncertainty of the model is to aggregate all the possible outcomes and average their probabilities of being included into the regression, thus, Bayesian Model Averaging (BMA) method was created. Using BMA, it is possible to address not only a single model, but millions of models which could potentially be constructed in order to estimate the effect of a particular bundle of factors on economic growth. BMA allows combining the output of millions of linear regressions. BMA allowed to account for more factors, mitigate the model uncertainty problem, and find previously unobserved factors (Raftery, 1995).

The process of determining the appropriate factors of economic growth is still an open question. Since regions individual growth rates contribute to the overall growth of the economy in a country, there is a need for regulators to understand what policies and structural reforms should be implemented to boost the regional growth. Researchers continue to find alternative determinants of GDP growth using various techniques, statistical models, and unique datasets. Consequently, despite a huge pool of factors being already discovered, there are many more that still are unknown. Therefore, the authors formulate the following research question: What are the determinants of economic growth of European Union NUTS2 regions?

The article is structured in the following way: section II reviews the existing literature regarding the economic growth and analyses the advantages of a wide variety of methodologies applied in growth econometrics. Section III describes the BMA methodology employed in this article. Section IV describes the data, and Section V provides empirical results. Section VI discusses the determinants of economic growth. Section VII finalises with the concluding remarks and the potential improvements of the research. 


\section{LITERATURE REVIEW}

The economic growth has been one of the most researched topics since the middle of the $20^{\text {th }}$ century. Countries strive to boost the economic development; however, after every year with a positive economic growth, it becomes harder to achieve high growth rates. Larger economies are challenged to achieve high growth rates per capita by their increasing income level per capita. The graph below explicitly depicts the absolute convergence, the effect when regions with higher GDP per inhabitant have lower economic growth (Figure 1).

In this case, the absolute convergence can be reflected on the regional level as well. The regions with GDP level per inhabitant higher than 10'000 EUR PPP per capita experience an average growth of $1.57 \%$; however, regions with lower income $(<10$ '000 EUR PPP) experience the average growth of $4.67 \%$. In turn, the idea of conditional convergence is that poor countries tend to grow faster than rich countries if they have similar equilibrium income level. In other words, Germany would require much larger effort to achieve growth of $4 \%$ than Latvia, because it already has a higher income level per capita.

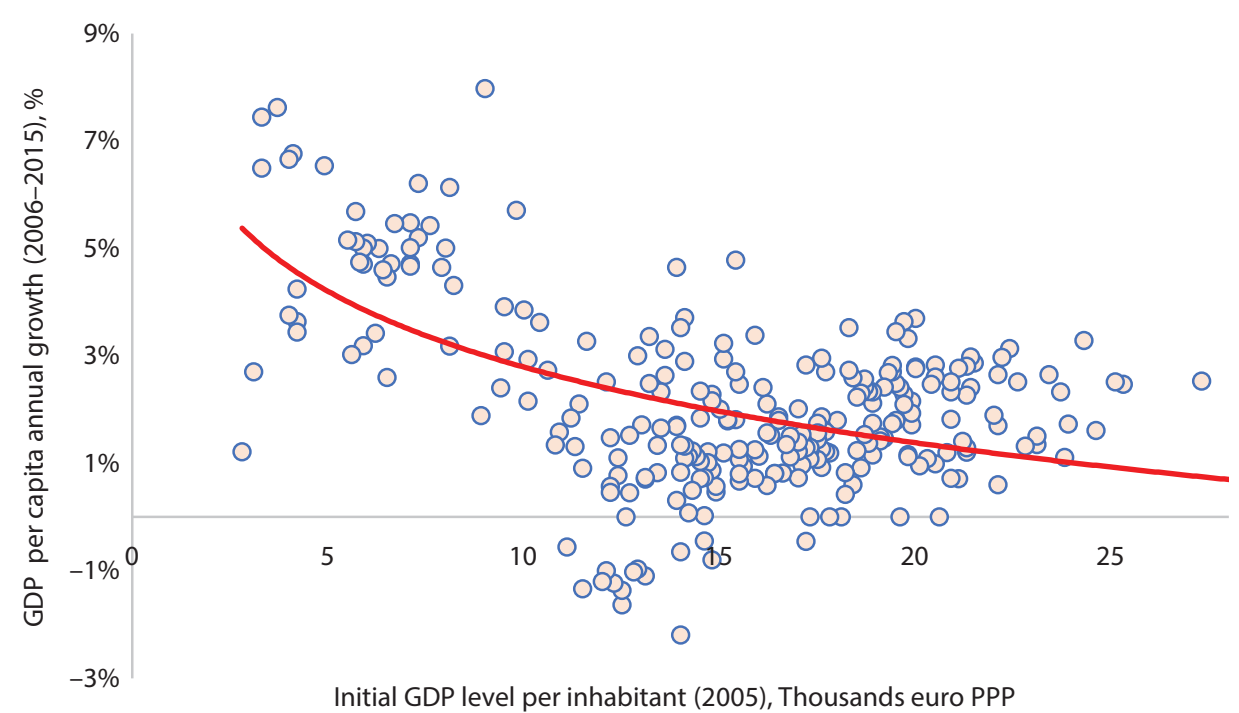

Source: Graph created by the authors using Eurostat

Fig. 1. Absolute Convergence in EU NUTS2 regions during 2006-2015

Consequently, the instruments of economic growth have been actively researched using various econometric models and statistical techniques starting from simple OLS up to Bayesian Econometrics. The models were tested on crosscountry and cross-region levels. The authors will discuss the studies of economic growth using various methods and different levels of aggregation in detail. 


\section{MAIN APPROACHES TO STUDY THE DETERMINANTS OF ECONOMIC GROWTH}

The neoclassical growth model, introduced by Solow (1956) and Swan (1956), shows that GDP per capita converges over time. The original theory postulates that there is a negative relationship between the income level and income growth. Notably, this does not imply absolute convergence yet, because countries may strive for their individual steady-state growth rates.

One of the most important contributions using variables outside the original theory to explain economic growth was done by Barro (1991). He tried to explain growth by adding 16 different variables to original theory to describe the productivity growth. However, the main problems he faced using standard OLS model was the heterogeneity problem and simultaneous causality. The direction of causality between economic growth and some possible growth determinants (institutions and macroeconomic factors, for instance) is not clear. Since the findings are subject to bias, they must be analysed cautiously. As an alternative, Sirimaneetham \& Temple (2009) compare results of OLS and 2SLS models. Although 2SLS has an undebatable advantage over simple OLS in mitigating causality issues, it is weakly robust in practice. The reason is that it is challenging to find proper instrumental variables that would describe a determinant and at the same time have a 0 correlation with the dependent variable, GDP growth. 2SLS approach has not found enough support due to its limited applicability.

Another way to determine productivity growth is to apply nonparametric production frontier approach (Henderson and Russel, 2004). Traditional parametric tests always assume a normal distribution of the data. However, the normal distribution is often overused in academia and even GDP growth with a large data set might be skewed to one of the sides. In this case, nonparametric tests allow the researchers to relax the assumption of normal distribution of the data and get closer to the real data distribution. Importantly, if any of the parametric tests are valid then non-parametric tests will provide spurious results. The drawback of the model is that it gives too much weight on data distribution which might be quite arguable.

However, employing different factors of economic growth in the model raise another econometric problem - model uncertainty. In a simple Ordinary Least Squares estimation, by adding an additional variable to the model there is some probability of receiving a significant determinant just by chance. Statistically, one might expect 1 out of 10 determinants to be significant at $10 \%$ significance level. This raises the ambiguity of any results. One of the examples is excluding fundamental Solow-predicted variables such as technological change has led to controversial results that growth is boosted by indefinite investments in human capital so that countries with higher initial income might have higher economic growth (Romer, 1986; Lucas, 1988). The absence of conditional convergence must be cautiously considered. There are three problems that might appear when empirically modelling conditional convergence process. (1) Due to model 
specifics, the absence of initial income in a model can lead to uncertain results since initial income has proven to have a strong correlation with GDP per capita growth (Temple, 1999). (2) There is a certain initial income threshold below which conditional convergence may not take place (Azariadis \& Drazen, 1990). (3) There are certain issues with endogeneity. Hence, the authors included initial income in the regression, and, luckily, are not exposed to the second issue since none of the European regions live under the growth threshold. To deal with the third issue the authors used lagged values of given variables. The authors included independent variables as close as possible to the beginning of the period under consideration.

There are several methods to mitigate model uncertainty - extreme bound analysis, BACE, and BMA. Under extreme bound analysis, if the factors change the sign over different models they are not regarded as robust determinants; however, if the factors retain the sign in different model sets, the determinant is considered robust (Levine \& Renelt, 1992). Contrary, Hoover and Perez (2004) argue that extreme bound analysis makes some of the important variables appear to be weak determinants, but some independent variables spuriously appear to be significant.

The most recent development in models of economic growth includes Bayesian approaches to estimate the posterior probabilities. The beauty of Bayesian econometrics is model uncertainty mitigation. Since previous models are compatible, the Bayesian approach allows to put all the models in one place and estimate the average coefficient out of all models. Sala-i-Martin (1997) suggests estimating the robustness of findings by applying Bayesian Averaging Classical Estimates (BACE). He proposes giving a weight to each model that sum of all the weights is equal to 1 . The weights should represent the likelihood of each model. Nevertheless, the equal weighting is applied. This model allows testing many determinants at one time, but the choice of a prior ${ }^{2}$ remains a subjective judgment. Also, BACE gives an equal weighting to each of the models whereas some models are superior to other based on historical prove or correlational analysis (Sala-i-Martin, Gernot and Miller, 2004)

The further research applies model averaging techniques, or Bayesian Model Averaging technique to correctly evaluate the robustness of findings. In contrast to BACE, BMA does not assign an equal weight to each model, but chooses the best model out of all. In fact, BMA does $2^{K}-1$ regressions (K stands for a number of explanatory factors). For illustrative purposes, if one applies 30 different factors to explain GDP growth, BMA would run more than 1 billion models. In such a large pool of models, each theory is tested and provides an aggregate outcome (Sala-i-Martin, 1997; Eris \& Ulasan, 2013; Danquah, Moral-Benito, Ouattara, 2014; Zeugner \& Feldkircher, 2015).

Eicher et al. (2007) adjust BMA to Iterative Bayesian Model Averaging (IBMA) "because the simultaneous consideration of model uncertainty and

2 Prior - initial model's prediction about probability distribution of the variables. 
parameter heterogeneity in standard growth regressions increases the number of candidate regressors beyond the processing capacity of BMA" (Eicher et al., 2007). The adjustments allow making a conclusion that a long list of regressors that most of the authors applied in cross-country data does not explain economic growth determinants in OECD. This is to say that economic growth yet remains a puzzle even on the cross-country level as well as on the region-specific level.

\section{EXPLORING ECONOMIC GROWTH DETERMINANTS ON A COUNTRY-SPECIFIC LEVEL}

The findings of conditional convergence go down to Solow (1956) and Swan (1956) starting with neoclassical growth model described above. Solow and Swan (1956) define GDP as a function of investments (I), total factor productivity level (A) and labour endowment (L). Mankiw, Romer, and Weil (1992) argue that productivity parameter, A, should not only account for fixed productivity level and technology, but also for country-specific effects on growth. Many cross-country studies have tried to build up on the previous research by extending the variable set determining A. Although Solow and Swan assumed total factor productivity (TFP) being the same over the long run, this is hardly realisable since TFP is constantly growing and additional factors help to explain the growth (Temple, 1999). Hence, further research of economic factors determining the convergence is split between the two groups: Solow growth model and growth determinants outside original theory (Durlauf, 2005).

One of the most popular contributions using alternative variables to explain economic growth was done by Barro (1991). Barro tried to explain economic growth with such variables as primary schooling, GDP levels at different periods of time, literacy rate, fertility rate, mortality rate, secondary-school enrolment rate and many others. He states that poor countries will catch-up if they have high human capital per capita; growth per capita and investment rate negatively relate to government consumption, because government distorts the growth with high taxes; economic instability has an inverse relation to economic growth. Indeed, economic stability plays a significant role in economic growth. Although when enough economic stability is in place institutions do not contribute to economic growth (Sirimaneetham \& Temple, 2009). Likewise, the authors reflect to a finding of Azariadis and Drazen (1990) that there should be a certain amount of initial income and degree of stability for conditional convergence.

Since the middle of the $20^{\text {th }}$ century, the debate about determinants outside original Solow theory was widely discussable. For instance, several authors are claiming that by applying various determinants the effect of economic convergence can be confirmed only with initial income and investments (Levine,Renelt, 992). Contrary, other researchers prove that there are plenty of other variables that can explain economic growth. As such political institutions (Acemoglu \& Robinson, 2001), real exchange rate (Easterly and Levine, 1997) 
or specifically capital accumulation should have had economic effect on the economic convergence. Indeed, capital accumulation takes a significant stake in the process of determining the labour productivity. It does include both physical and human capital which account for $90 \%$ increase in output, while an increase in TFP accounts for the remaining 10\% (Henderson and Russel, 2004).

It is important to note that the finding may differ from region to region. For instance, when Eicher et al. (2007) analysing developed OECD counties does not find any effect of industry structure on economic growth, however, Masanjala and Papageorgiou (2008) analysing African region find mining sector significantly contributing to economic development. This might be one of the reasons the variables outside original theory may differ from region to region.

Another approach to economic growth is the analysis of a spatial effect (the neighbouring countries positively affect the GDP growth). For instance, fast developing countries may positively affect the neighbouring country. LeSage et al. (2008) take a new approach to the effect by applying Spatial Durbin Model (SDM), Spatial growth regression and compare the results to the BMA using region-specific data. They found that long-run steady-state regional income depends on own region, neighbouring region characteristics, the spatial connectivity structure of the regions and the strength of spatial dependence. Their finding was that the spatial spillover impact on neighbours is negative, while own regions positively affect the economic growth; consequently, the overall effect is ambiguous (LeSage et al. 2008).

Finally, M. Danquah (2013) combined non-parametric DEA approach with BMA approach to find the effect of geographic, institutional, macroeconomic variables, trade openness, factor supply variables, and institutional variables on the economic growth. Danquah et al. (2014) postulates that the key determinant of TFP growth is trade openness, initial GDP, and unobserved heterogeneity during the estimation period 1960-2000.

\section{EXPLORING ECONOMIC GROWTH DETERMINANTS ON A REGIONAL LEVEL}

The researchers apply like cross-country growth factors, but regional level allows the use of additional explanatory variables that are different across the regions within a country, and consequently, new discoveries and approaches to economic growth.

According to Lall \& Yilmaz (2001), public capital and human capital do not contribute to the speed of convergence, because temporal economic behaviour and regional differences have much larger effect on economic convergence. In contrast, Gonzalez \& Montolio (2004) support the idea that public investments would increase the economic growth; while Cuaresma et al. (2014) and Kaldewei, C., \& Walz, U. (2001) argue that human capital matters on a regional level. Cuaresma runs a BMA model proving that increase in $10 \%$ population share 
of workers with higher education is associated with $0.6 \mathrm{pp}$ higher annual growth rates of GDP per capita in European regions.

Interestingly, the spatial effect of human capital has positive effect on economic growth (Lall \& Yilmaz, 2001; Magrini, 1998). The free movement within the EU allows people to migrate with no problem. Policies against the barriers for factor mobility might be critical for the fast economic convergence. Contrary, Polasek and Berrer (2006) claim that migration is no always good. Due to free movement, countries are not able to stop the migration in critical cases. They claim that almost a half of the observed regions in the sample is not able to avoid decreasing demographic trend and will shrink. Also, Kaldewei, C. \& Walz, U. (2001) find no significant effect from migration of human capital on economic growth.

Furthermore, the presence of universities in the regions positively affects the economic growth (Magrini, 1998). Universities affect the growth both directly and indirectly. Either universities are a research producer, or they provide human capital, both types of contribution positively increase the economic growth.

Other important economic growth determinants on a regional level coinciding with original theory are investments and initial income (Ledyaeva \& Linden, 2008; Błażejowski et al., 2016). However, investments being one of the main growth determinants in Solow growth model reduce its significance on the regional level (Kaldewei \& Walz, 2001). Alternatively, larger investments in the industrial sector share proven to contribute more to economic growth than diversified investments in different industries (Magrini, 1998). The specialisation in one segment brings more benefits rather than spreading the investment portfolio among different industries. Nevertheless, investments in the manufacturing sector do not contribute to economic growth (Polasek and Sellner (2013).

Another way to explain economic growth is by adding fixed effects (Ding \& Knight, 2011; Cuaresma et al., 2009; Cuaresma et al., 2014). The researchers have proven that capital cities tend to grow faster on average, as well as country specific effects are significant for some regions. They also provide the significant effects from regions located near the sea and within the pentagon area. There should be some other growth determinants within the area of fixed effect determinants that would explain the economic growth in the region. In fact, fixed effects are good control variables, but have almost no explanatory power. Additionally, the coastal effect has been proven to be insignificant in the latest research by Ding \& Knight (2011).

The interest of this article is to find the uncovered explanatory variables and justify the statistical significance with economic reasoning. Although various studies applying BMA approach have been consistent in some growth determinants (Initial GDP, investments), they have also found additional determinants that are specific to each country or region. The idea of applying BMA to region-specific level allows realising alternative growth determinants that have not been considered before. Hence, the goal of the article is to 
understand why some growth determinants appear to be significant; explain why some regions tend to grow faster than others; and discover new growth determinants.

\section{METHODOLOGY}

BMA is a standard approach to both account for model uncertainty and handle large datasets. In order to evaluate potential growth determinants, the authors use two different approaches: the cross-section of regions, the crosssection of regions with a spatial autoregressive (SAR) structure suggested by Cuaresma, Doppelhofer and Feldkircher (2009). Applying it together with the methods proposed by Levine and Renelt (1992) and Sala-i-Martin (1997), we run the following linear regression with $\mathrm{K}+\mathrm{F}$ variables in an $\mathrm{N} \times \mathrm{K}+\mathrm{F}$-dimensional matrix $X$ :

$$
y=\alpha i_{N}+\beta_{F} X_{F}+\beta_{K} X_{K}+\rho S Y+\varepsilon
$$

where an $\mathrm{N}$-dimensional column vector $y$ is economic growth for $N$ European Union regions (NUTS2), $\alpha$ is the intercept term, $i_{N}$ is an $\mathrm{N}$-dimensional column vector of regions. We divide variables into two groups: factor accumulation/ convergence variables $\left(X_{F}\right)$ used by Solow-Swan and the rest variables $\left(X_{k}\right)$ that can explain total factor productivity (TFP) differences between the regions, which are represented as $\beta-a K+F$-dimensional vector of regression coefficients, being equal 0 if no regressors added. Additionally, the authors include in the regression spatial dependence structure and denote it with the variable $S$, which is an $N \times(N-1)$ matrix and $\rho$ being a degree of spatial autocorrelation, which is also represented as $N \times(N-1)$ matrix. Non-zero $\rho$ indicates the presence of spatial effect among the regions. Two approaches could be used to measure degree of spatial autocorrelation: (1) distance metrics, where distances might be calculated based on the centroid of the regions or (2) equal weight for all region's neighbours (LeSage \& Parent, 2007). Finally, $\varepsilon$, an $N$-dimensional shock follows a normal distribution with zero mean and identity variance-covariance matrix.

The authors apply Bayesian Model Averaging (BMA) approach and add prior distribution for the parameters. The authors' focus is to compare the models with a diverse set of explanatory variables. According to Kass and Raftery (1995), the choice of the prior has a significant impact on posterior inclusion probabilities of the model. Fernandez, Ley and Steel (2001) proposed uniform prior $\rho=2^{-K}$ on $\alpha$ and variance of the error term, which means that probability of adding a variable into regression is equal 0.5 exclusive of how many regressors are in the model, and g-prior on $\beta$. These priors are supported by LeSage and Parent (2006) and called "benchmark" prior distribution since these priors have a minor influence on the posterior distribution and overall results. Thus, the authors apply the uniform and g-prior combined for sampling distribution and state that the probability that one variable appears in the model is independent of other variables. 
Model uncertainty given the data (D), if $\beta$ is the coefficient of interest, can be assessed by weighing the uncertainty of all individual models. Models $M_{1}$, $M_{2}, \ldots, M_{K}$ are mutually exclusive and exhaustive. The authors use posterior inclusion probabilities (PIP) to determine variable's significance in determining the regional growth level. Posterior inclusion probability, denoted as $p\left(M_{i} \mid D\right)$, is calculated using equation (4) and Bayes rule as a sum of probabilities variable $X_{K}$ being included in the regression.

$$
p\left(M_{i} \mid D\right)=\frac{p\left(D \mid M_{i}\right) p\left(M_{i}\right)}{\sum_{k=1}^{2^{K}} p\left(D \mid M_{k}\right) p\left(M_{k}\right)}
$$

where $p\left(M_{i}\right)$ is a probability of the $M_{i}$, which belongs to the sample of all the $2 \mathrm{~K}$ models; $p\left(D \mid M_{i}\right)$ is a probability of $\mathrm{D}$ given the model $\mathrm{i}\left(M_{i}\right)$ and a probability of the data (D) given the model $\mathrm{M}_{\mathrm{i}}$ equals:

$$
p\left(D \mid M_{i}\right)=\int p\left(D \mid \beta_{x}, M_{i}\right) p\left(\beta_{x}, M_{i}\right) \Delta \beta_{x}
$$

where $p\left(D \mid \beta_{x}, M_{i}\right)$ is the observed likelihood, whereas $p\left(\beta_{x}, M_{i}\right)$ is prior density.

The authors repeat the same analysis for spatial autoregressive (SAR) structure by running the regression with an inclusion of country fixed effects. After determining which variables are important in explaining economic growth at the regional level, we calculate the posterior mean (PM), the mean of the distribution of coefficients before the explanatory variables $-\beta_{\mathrm{k}}$.

The variance of the posterior density or posterior variance is determined as a sum of all conditional variances weighted across all the visited models with the estimated model uncertainties.

$P S D=\sqrt{\sum_{i=1}^{2^{K}} p\left(M_{i} \mid D\right) \operatorname{var}\left(\beta_{K} \mid D, M_{i}\right)+\sum_{i=1}^{2^{K}} p\left(M_{i} \mid D\right)\left[E\left(\beta_{K} \mid D, M_{i}\right)-E\left(\beta_{K} \mid D\right)\right]^{2}}$

The results are analysed using Bayesian credible interval equal to $95 \%$. This implies that with a large number of models observed, with $95 \%$ probability the true value will be within a given interval.

Lastly, the authors ensure that the results obtained using two different specifications are robust. An econometric theory does not provide the specific methodology for finding spillover weights in matrix $S$, the authors do a sensitivity analysis and adjust weights based on regions GDP per capita PPP.

\section{DATA}

The data include statistics on 276 European regions at second-level of Nomenclature of Territorial Units for Statistics (NUTS) classification valid from 1 January 2015 in the time period 2006-2015. The authors take a NUTS2 regions instead broader set of NUTS3 regions (1347), because of data availability. 
In order to collect yearly data for possible determinants, the authors use ESPON (European Spatial Planning Observation Network) database for:

- Infrastructure variables, such as density of transportation network (e.g. rail density, road density), network connectivity and accessibility;

- Variables such number of nights spend by tourists, different types of emissions of carbon dioxide, and number of airports and seaports;

- Geolocation variables (Area, pentagon, coastal, capital city, etc.);

And EUROSTAT database to gather statistics on:

- Macroeconomic variables (Investments, initial GDP, industry structure, etc.);

- Demographic and human capital variables (Population growth, population, fertility, percentage of male population, level of educational attainment, etc.).

Moreover, the authors use an additional newly created variable - university top500 which is an index receiving value from 1 to 213 depending on the place in Shanghai Jiao Tong University Ranking 2005. The higher is the place in the ranking the bigger is the index value. 213 stands for the number of universities in Europe included in top 500 best universities ranking based on academic performance of the students - Nobel Prize and Field Medals winners, and bibliometric data. In case there are two or more universities within the area the sum of the respective indices is taken. This is a proxy for the quality of tertiary education in a region, since Shanghai Jiao Tong University Ranking 2005 is one of the top-ranking matrixes used to evaluate a university performance.

As a dependent variable, the authors take the average GDP per capita growth rate of the region from the year 2006 to 2015. The distribution of the dependent variable looks like a normal distribution (Figure 2).

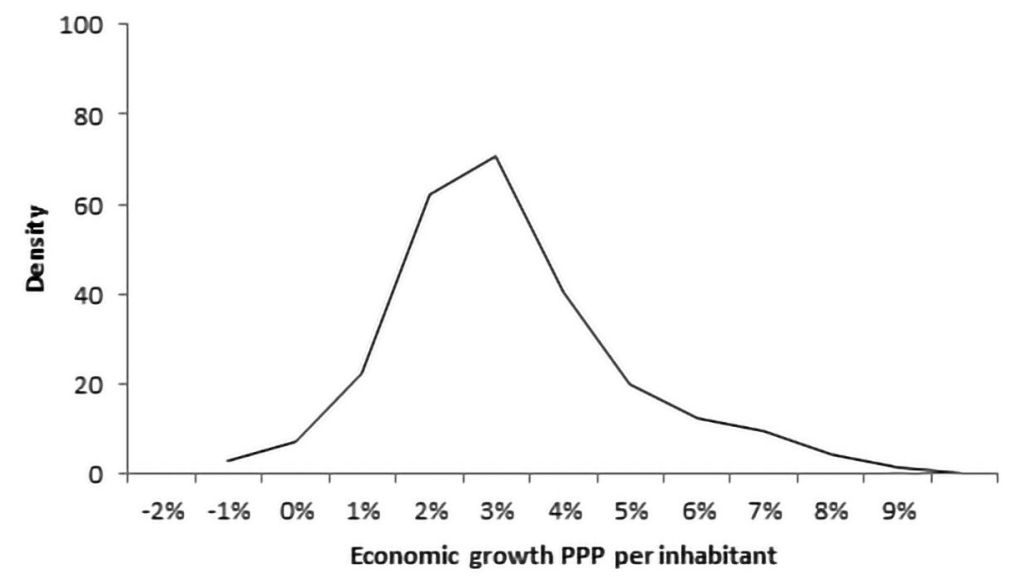

Source: Graph created by the authors using the data described in the Data section

Fig. 2. Distribution of average GDP per capita growth PPP of EU regions in the period from 2006 to 2015 
Despite Barro and Lee's (1994) finding that endogeneity had minor effect on coefficient estimates, the authors share Caselli F., Esquivel G., Lefort F. (1996) opinion that endogeneity plays a significant role in driving standard results in growth empirics. In order to mitigate the problem of endogeneity, the explanatory variables enter the model as close as possible to the beginning of the observed period.

Some of the variables are adjusted to country's area or population. This allows obtaining determinants which can be compared across the regions. The authors also adjust other types of variables: the authors calculate the shares of different types of patent from total amount of patents in the region to assess the technological innovation of the region, as well as, compute the shares of the workers with tertiary, secondary and primary education as a measure of human capital in a region.

The authors observe the following complications with the obtained statistics. First, European Union regional NUTS2 classification has changed, resulting in increasing number of regions. Thus, data collected prior to changes in classification will miss observations for newly created regions. Secondly, some of the determinants have missing values on NUTS2 classification or are reported using NUTS3 classification. Therefore, the authors adjust the data from NUTS3 regions into NUTS2 regions by either taking average of the NUTS3 value that constitute to NUTS2 or taking a sum of all NUTS3 region values.

All things considering, the list of the variables sums up into 42 potential regional growth determinants in a regional level.

\section{RESULTS}

The empirical results imply that economic growth can be determined by the following factors: population share with primary education, initial income level, population aged 30-49, share of industry in gross value-added, share of patents in information and communication technologies (ICT), spatial effect, pentagon effect, $\mathrm{CO}_{2}$ ground emission, coastal effect, population growth effect, capital city, and universities which are included in top 500 Shanghai Jiao Tong world university ranking. The results are analysed using Bayesian credible interval equal to $95 \%$.

Moreover, referencing to Ley and Steel (2009), the authors decided to use Beta-Binomial model prior, since the authors aimed to focus the distribution with prior model size (Figure 3). Due to primary sorting, the authors decreased uncertainty around the model size, thus, this prior reduces the risk "unintended consequences from imposing a particular prior model size" (Zeugner, 2011). The authors don't specify draws and burnins since the amount of the models can be assessed using the author' computational systems. 
Cross-section BMA regression

Table 1

\begin{tabular}{|l|c|c|c|c|}
\hline & PIP & $\begin{array}{c}\text { Posterior } \\
\text { Mean }\end{array}$ & Posterior SD & $\begin{array}{c}\text { Conditional } \\
\text { Sign }\end{array}$ \\
\hline Primary education share & 1.0000 & -0.0516 & 0.0058 & 0 \\
\hline Initial income level & 0.9999 & -0.0000 & 0.0000 & 0 \\
\hline Population (30-49) share & 0.9999 & 0.2311 & 0.0493 & 1 \\
\hline Industry share in GVA & 0.9998 & 0.0454 & 0.0096 & 1 \\
\hline ICT patents share & 0.9989 & 0.0152 & 0.0037 & 1 \\
\hline Spatial effect & 0.9957 & 0.1286 & 0.0355 & 1 \\
\hline Pentagon & 0.9953 & 0.0065 & 0.0018 & 1 \\
\hline CO, ground & 0.9727 & -0.0042 & 0.0014 & 0 \\
\hline Capital City & 0.7943 & 0.0041 & 0.0029 & 1 \\
\hline University ranking & 0.7117 & 0.0000 & 0.0000 & 1 \\
\hline Coastal & 0.6726 & -0.0018 & 0.0017 & 0 \\
\hline Population growth & 0.4100 & -0.0528 & 0.1060 & 0 \\
\hline Mean No. regressors 10.5515 & Prior Model Size 6(Random) & \% of models visited $100 \%$ \\
\hline
\end{tabular}

Note. Conditional sign represents in what percentage of the models the factor has positive sign. 1 shows that factor has a positive sign in $100 \%$ of the models, while 0 shows that factor always has a negative sign.

Source: created by the authors using the data described in the Data section and RStudio software.

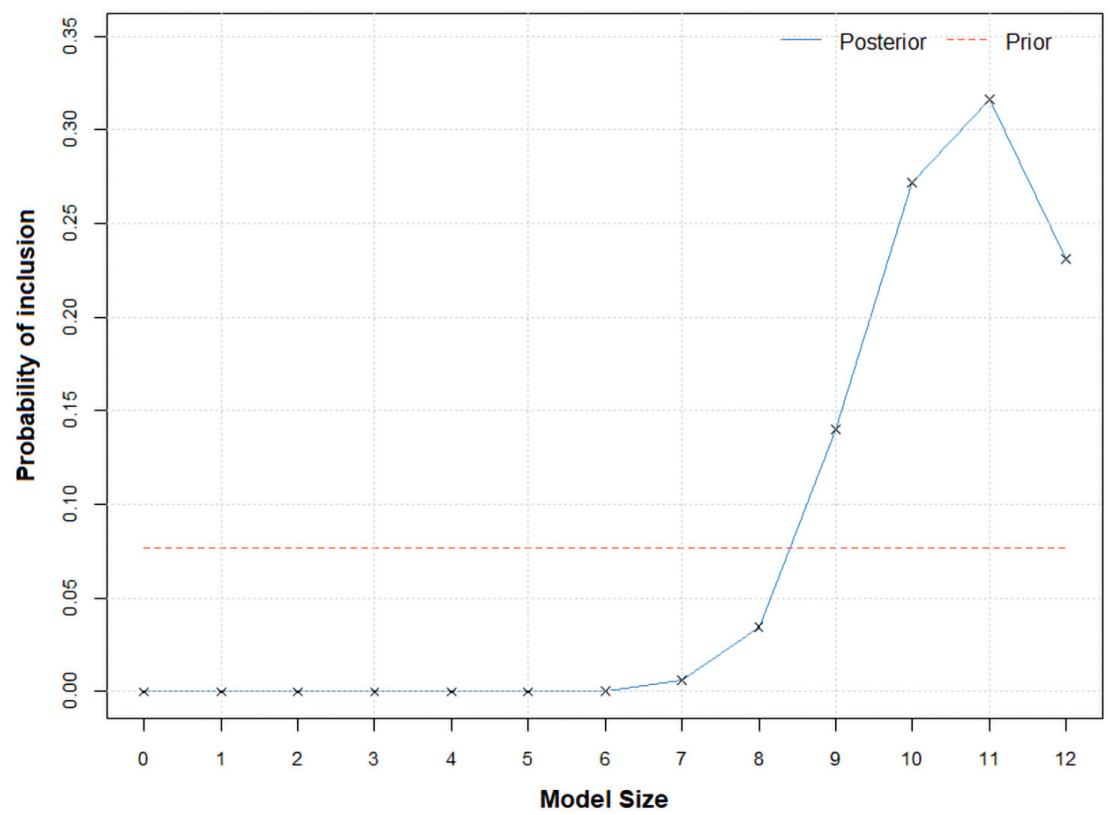

Source: Graph created by the authors using data described in the Data section.

Fig. 3. Posterior Model Size Distribution graph 
The best model explains $23 \%$ of the total cumulative model probabilities. From Figure 4, one can observe that posterior inclusion probability of initial income is very close to $100 \%$. Additionally, it is negatively related to income growth, thus, the presence of conditional convergence is observed. In other words, when controlling for other factors, the lower is the initial income the higher is the subsequent economic growth.

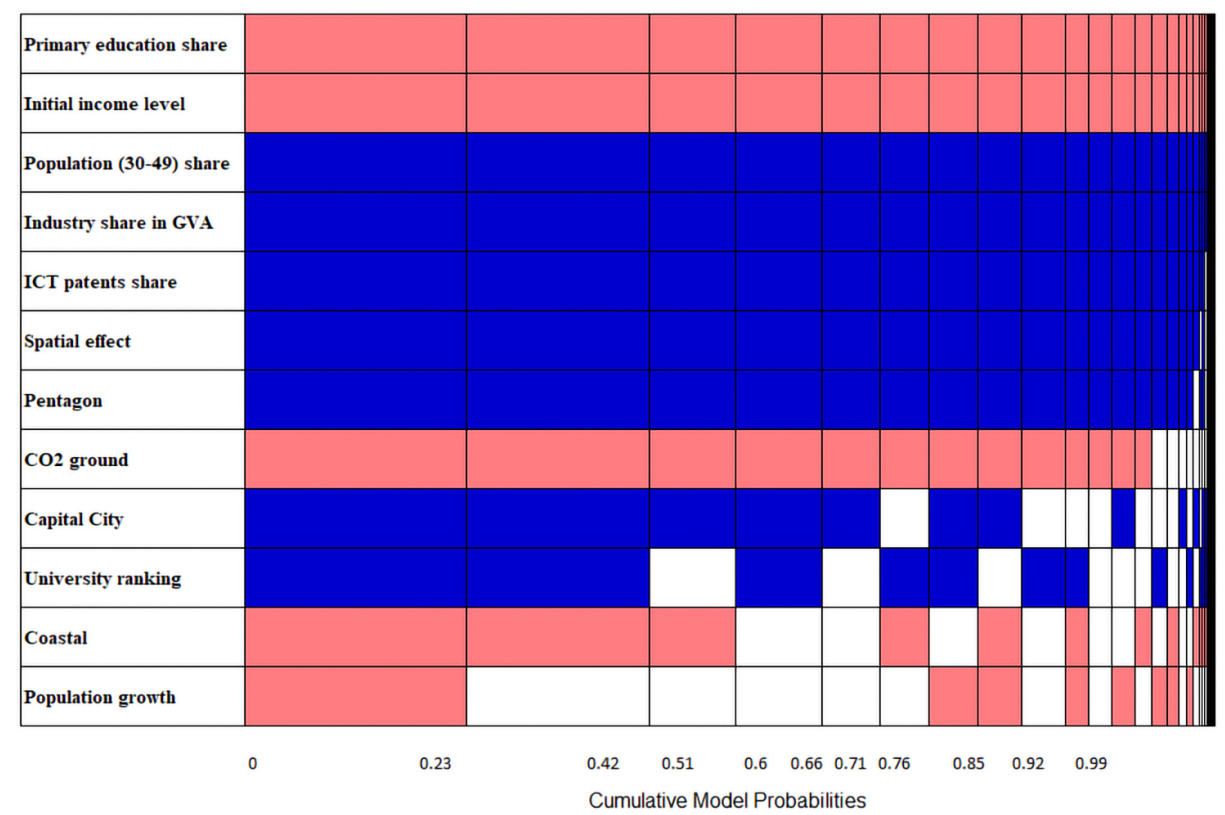

Source: Graph created by the authors using the data described in the Data section and RStudio software.

Note: Blue colour (dark in black and white version) represents a positive relationship with GDP PPP per capita growth, while red colour (light in black and white version) represents a negative relationship. White areas show that variable was not included into the model.

Fig. 4. Cumulative Model Inclusion Probabilities based on the best 500 models

The most significant negative relation with economic growth has a share of poorly educated people. The more people have only primary education in a region the lower is the economic growth. This creates a bound to the possible explanation of economic growth - the more educated population the higher the economic growth. In fact, Li, Loyalka, Rozelle, and Wu (2017) argue that human capital accumulation matters depending on the state of the country. For a lowincome country to reach the middle-income level a centralised mechanism for a mandatory pre-tertiary education is required; however, in order to jump to a high-income level, a decentralised tertiary education mechanism is required. Moreover, the significance of poorly educated population supports the inclusion of the variable representing an index of universities being in top 500 ranking. 
In other words, low education variable shows the number of educated people in the region, but variable representing top 500 universities describes the quality of tertiary education in the respective territory.

The authors found that prime age has a significant positive relationship with GDP per capita growth and has a $100 \%$ posterior inclusion probability. The authors tested various age groups such as 30-34, 30-39, 30-44, 30-49, 35$59,35-45$, etc, and by including different age groups, the authors managed to understand that prime age population for European Union NUTS2 regions are people aged 30-49. Similarly, Gomez and De Cos (2008) find that increase in prime age persons aged 35-54 relative to younger counterparts aged 15-34 has a positive effect on GDP growth. The larger the share of working population the more GDP per capita could potentially be created. The chosen period represents people that have already graduated from a university and have accumulated some working experience.

A variable representing the emission of $\mathrm{CO}_{2}$ has a posterior inclusions probability of $97.27 \%$ and it is negatively related to economic growth. This might be explained by the fact that there is too much ground transport in the regions, and cars can be declared as not one's assets, but rather a liability or bad investment. Also, this could be explained by the fact that the more cars are on the street the more pollution is present, thus, the more polluted regions develop slower when controlling for other factors.

Moreover, a share of information and communication technologies appears to be a good predictor of economic growth. The positive sign could relate to the ease of information access and consequently a faster growth (Farhadi, Ismail \& Fooladi, 2012). Potential explanation could be that with an intense technological development the ICT might affect the GDP growth much stronger in 2018. For this study the authors used the ICT data from 2005 - when the information technology was not as broadly accessible as it is now. Thus, the effect of ICT might have an even higher correlation with GDP growth in 2018 than in 2005.

Population growth has a negative relation with economic growth, which is in line with the Solow model and the preceding literature. Logically, the higher the population growth the lower the income growth per inhabitant.

In turn, the spatial effect, being calculated using second method described in the methodology section, appears to be significantly and positively contributing to economic growth. The finding goes in line with Cuaresma (2014) with a posterior inclusion probability of $99.57 \%$. Meaning that regions with a fast economic growth increase economic growth of neighbouring regions, which, later on, might benefit them back. This fact also could indicate that having no trade or travel barriers might be the prerequisite for higher spillover effect.

Interestingly, pentagon area has a positive economic effect on economic growth, which coincides with the results of Cuaresma et al. (2014). This means that there is a certain determinant within the area of the pentagon that would explain the growth. In turn, coastal regions tend to grow slower on average. 
Although, the cities located near seas have an additional trading channel merchant's vessels, there is another explanatory variable which decreases economic growth. The authors tried to check this by adding variable representing the a mount of nights spent in a hotel by tourists in the region, however, it ends up being insignificant; while variable Coastal retained its significance level. These issues are a great focus for the further research.

Lastly, following the findings of Cuaresma (2009), capital city regions tend to grow faster than other regions, keeping all other factors constant. Hence, the capital city variable, being a dummy variable, has a potential determinant that would explain the growth of the region. The authors tried to explain the capital city variable by applying a unique determinant - an index which is assigned to each region if a region has a university from top 500 Shanghai Jiao Tong university ranking in the world. The authors believe that quality of tertiary education in a region can foster the economic growth of a region.

In fact, the results are not so obvious. The capital city does not lose its significance in models with the given variables. The university variable explains the capital city growth for some models, but not enough to prove that it is the key determinant. This fact provides a space for further research, since a dummy variable should not be a significant factor because it might be not endogenous by itself; rather the capital city dummy depends on a wide variety of factors that are still to be researched.

\section{ROBUSTNESS CHECK}

The choice of the inclusion of each determinant is combined using a nested regression technique. It means that the authors added variables one by one in the regression and observe how the output has changed; this approach helps to define the specific set of variables that prove an economic meaning of the model. Hence, the authors started with a fundamental study by Solow and Swan (1956), which positions that investments have a positive economic effect on economic growth. Consequently, the next criterion to determine the best economic model is to identify variables that have proven to be significant in previous research. For instance, population growth has a negative effect (Mankiw, Romer and Weil, 1992; Kelley and Schmidt, 1995), positive spatial effect (Ciccone \& Hall, 1996), negative effect from initial income (Solow, 1956, Kormendi and Meguire, 1985; Barro, 1991), etc.

When all the variables are included, the significance level of the variables is far from being absolute. This problem is mainly because of correlation among explanatory variables (see correlation matrix in Appendix A). The authors excluded variables which had almost perfect positive or negative correlation. Another problem is a big number of dummy variables which were included in the regression. It leads to failure in regression analysis if the output of dummy variables can be perfectly predicted from the result of another dummy variable. 
Hence, the authors excluded all the country-specific effect in order to see the statistical reasoning of chosen variables, although country-specific effects proven to be important determinants of conditional convergence (Cuaresma et al., 2009). The authors also excluded variables with the least number of observations, for instance, variable representing average level of investments as a percentage of GDP in the years 2003 and 2005 is missing a lot of data and its inclusion will end up in a truncation of the data sample.

Lastly, it is important to carefully adjust the model with the variables which improve the statistical sense and economic meaning of the model. For example, unemployed aged 18-24, who also do not study in the university, appear to have a significant and positive effect on economic growth which contradicts the economic sense. One can argue that people aged 18-24 can take a part in shadow economy activities, however, the authors also adjusted the model for people with primary education. Interestingly, the variable representing people with primary education is significant in $100 \%$ of the models, while unemployed $18-24$ lose its significance level, therefore, its economic meaning, since these people have primary education. In this case, the authors excluded such variables from the final regression because their significance was explained by other economic determinants.

Once the authors added industry gross value added the investments are no longer significant in the model. It might reflect that investments in industrial sector take a significant part of economic growth (Table 2). Also, one would expect industrial gross value added to take the significance away from pentagon variable since there are plenty of industrial giants within the area of pentagon such as BMW, Volkswagen, Bosch, BASF, Airbus, etc. However, pentagon variable almost retained its significance level (Appendix B). This means that there are more variables that can explain significant abnormal GDP per capita growth level of the regions located within pentagon area.

Table 2

BMA regression: Explanation of Investments' significance level with Industry GVA

\begin{tabular}{|l|c|c|c|c|}
\hline & PIP & Posterior Mean & Posterior SD & Conditional Sign \\
\hline Nat_Income PPP per inh & 0.9993 & -0.0000 & 0.0000 & 0 \\
Population growth & 0.9969 & -0.8319 & 0.2126 & 0 \\
Investments & 0.9211 & 0.0615 & 0.0286 & 1 \\
\hline
\end{tabular}

\begin{tabular}{|l|c|c|c|c|}
\hline & PIP & Posterior Mean & Posterior SD & Conditional Sign \\
\hline Industry GVA & 0.9999 & 0.0774 & 0.0129 & 1 \\
Nat_Income PPP per inh & 0.9999 & -0.0000 & 0.0000 & 0 \\
Population growth & 0.4049 & -0.1528 & 0.2289 & 0 \\
Investments & 0.3757 & 0.0143 & 0.0230 & 1 \\
\hline
\end{tabular}

Source: Table created by the authors using the data described in the Data section and RStudio software. 
The regression (Table 3) showed that majority of the factors chosen and included indeed are related to economic growth. By applying OLS we check the robustness of the determinants. Evidently out of all factors only population growth loses its significance at $10 \%$ significance level, keeping all other factors constant.

Table 3

Linear regression: Spatial Autoregressive Model

\begin{tabular}{|l|c|c|c|c|c|}
\hline & Estimate & $\begin{array}{c}\text { Standard } \\
\text { Error }\end{array}$ & $\mathbf{t}$ value & $\operatorname{Pr}(>|\mathbf{t}|)$ & $\begin{array}{c}\text { Significance } \\
\text { level }\end{array}$ \\
\hline (Intercept) & -0.0206 & 0.0128 & -1.604 & 0.1100 & \\
ICT patents & 0.0149 & 0.0037 & 3.961 & 0.0000 & $* * *$ \\
Pentagon & 0.0062 & 0.0018 & 3.43 & 0.0007 & $* * *$ \\
Coastal & -0.0028 & 0.0014 & -1.891 & 0.0597 & $*$ \\
Capital City & 0.0051 & 0.0023 & 2.177 & 0.0304 & $* *$ \\
\hline Nat_Income PPP per inh & -0.0000 & 0.0000 & -5.465 & 0.0000 & $* * *$ \\
Population growth & -0.1290 & 0.1340 & -0.963 & 0.3364 & \\
Industry GVA & 0.0445 & 0.0097 & 4.593 & 0.0000 & $* * *$ \\
Population (30-49) & 0.2163 & 0.0476 & 4.536 & 0.0000 & $* * *$ \\
University ranking & 0.0000 & 0.0000 & 1.902 & 0.0584 & $*$ \\
Primary & -0.0499 & 0.0055 & -8.936 & 0.0000 & $* * *$ \\
CO ground & -0.0046 & 0.0013 & -3.493 & 0.0005 & $* * *$ \\
Spatial effect & 0.1278 & 0.0348 & 3.672 & 0.0002 & $* * *$ \\
\hline Significance codes: $* * *$ & $\mathbf{0 . 0 1}$ & $*$ 0.05 & $* .1$ \\
\hline
\end{tabular}

Source: Table created by the authors using the data described in the Data section and RStudio software.

Thus, the authors continued the analysis with Bayesian Model Averaging, in order to investigate what is the effect of these variables on economic growth in all potential models. Lastly, the authors investigated what is the most appropriate prior that should be used in BMA regressions. The authors concluded that due the notion that with sufficient data any low-information prior results will not change with the prior belief about the distribution of the parameters. Thus, the authors decided to use a Beta-Binomial model prior. The choose of this prior is in line with Carmen Fernandez, Eduardo Ley and Mark F. J. Steel paper that aims specified the usage of "automatic" or "benchmark" priors that can be applied in a situation with the large sample of visiting models (Fernandez et al., 2001).

\section{DISCUSSION}

The economic findings of the research have quite broad implications in policy analysis. Either the government or a local regulator can affect quite a few economic growth drivers. The complexity of the application of each variable is depicted on the Figure 5. 


\begin{tabular}{|c|c|c|c|c|c|}
\hline ICT & Popul & $30-49$ & op 500 & Capit & \\
\hline $\mathrm{CO}_{2}$ emissions & Industry GVA & Primary education & Spatial & effect & Coastal \\
\hline
\end{tabular}

Source: Created by the authors.

Fig. 5. Implication complexity of growth determinants

For instance, the regulator can boost industrial investments, or increase the tax on $\mathrm{CO}_{2}$ emissions to push up the economic growth in the region; or choose to increase government spending more in the information and communication technologies, as well as attract the middle age (30-49) population from abroad. To ensure that regions have enough funds to stimulate the economy, these policies might be implemented together. Therefore, funds for additional investments in industrial sector can be collected from increased taxes on $\mathrm{CO}_{2}$ emission.

Although almost all the determinants require additional investments, some variables also require a significant amount of time to be implemented. One of the policies which is difficult to stimulate would be boosting education level. Although the major economies have a mandatory primary education, the higher education still remains an individual choice. The complexity comes when economic growth is determined by the inclusion of top 500 best universities in the world's rating and explaining the capital city effect. Although the capital city effect has decreased when controlling for best universities in the world, yet it is not excluded completely because some of the top world schools simply are not located in the capital city. For instance, such top-class universities as the University of Oxford, University of Cambridge, Utrecht University are not located in the capital city. Sometimes they could be even far from the capital city, but being one of the top schools in the world. Capital city effect does not lose its effect completely, but it is still decreased, because there are some top schools that are located in capital cities. For example, London School of Economics, Imperial College London, University Paris Sud, University of Helsinki, etc. are located in the capital city and boost the regional growth. In fact, this supports the argument that education is one of the significant determinants of economic growth since only a few universities located in the capital city were enough to decrease the posterior inclusion probability of the dummy variable from $87.74 \%$ to $79.43 \%$. Moreover, in order to get a decent place in the ranking, a sufficient investment and time resources are required.

Furthermore, variables such as coastal or pentagon are time-invariant and cannot be stimulated or changed. Either a country does have access to the sea or it does not; or it is located in the pentagon area, or is located outside. Nevertheless, these variables are related to economic growth and, despite the inclusion of other variables, retain its high significance level. A potential explanation of the significance level of pentagon variable might be a unique set of the regions which are part of pentagon area. Such cities as Luxembourg - banking centre of Europe, 
which is growing on 91 basis points faster than average region in European Union during the period from 2006 to 2015; or Milan - Europe's most famous shopping city positively contributes to the growth of the region. Moreover, the major part of the pentagon area belongs to Germany. Growth rate of Germany is on 68 basis points higher than the average regional growth in European Union during the period from 2006 to 2015. Nevertheless, when controlling for industrial sectors and tourism the pentagon variable still retains its significance.

Coastal variable is negatively related to economic growth. One of the potential explanations might be the fact that regions near the seas developed earlier, thus, now have higher initial income and consequently lower growth rate. The remaining posterior inclusion probabilities might be due to the fact that coastal regions have an additional exposure to risks, such as a high exposure to tourism sector, thereby, exposure to seasonality issues; and additional non-related to economic development government spending, such as investments in cultural events, reconstructions, art or architecture. Analysis of regional unemployment level, government and consumer spending potentially can provide more coherent information and decrease significance level of the coastal determinant.

Nonetheless, the implication of each variable would have boosted the economic growth in a region, thus, to robustly estimate the effect of an economic policy in an individual region, the authors predict the economic growth of each region by the model (Appendix $C$ ). In fact, the value of $\mathrm{R}^{2}$ suggests that predicted variables can explain about $70 \%$ of the actual economic growth during 20062015 period (Figure 6).

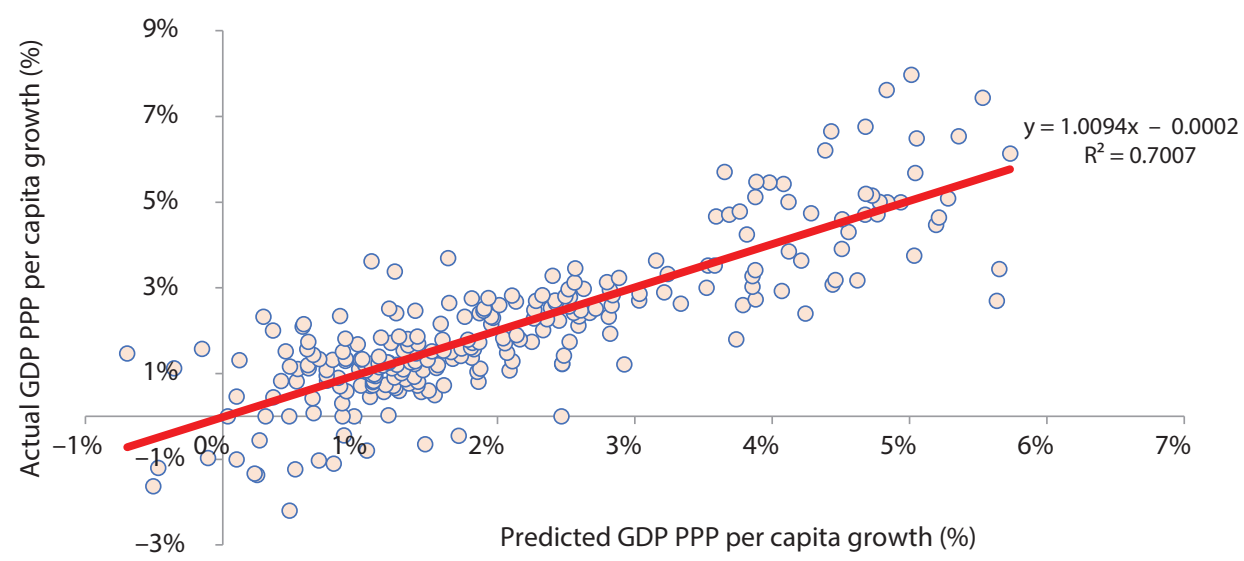

Source: Graph created by the authors

Fig. 6. Predicted economic growth per capita growth rate versus actual economic growth per capita growth rate

The $\mathrm{x}$-axis depicts the predicted growth rate per capita, while the $\mathrm{y}$-axis shows the actual growth rate per capita. Ideally, the closer is the red line to the symmetric 
function $f(x)=x$, the better results are predicted. Nevertheless, the authors observed a slight bias towards positive growth; yet the trend line is quite close to being fully symmetric. For example, Campania, one of the slowest growing regions, has an economic growth rate per inhabitant equal to $0.45 \%$, whereas, the model predicts the growth for the region of $0.37 \%$; or Opole Voivodeship, small province in Poland and one of the fastest growing regions, has growth rate of $5.09 \%$, whereas the model predicts the growth rate per inhabitant of $5.28 \%$ (Appendix C). Indeed, the model is biased towards an average region and is less evident when outliers or rare cases appear. For instance, Bucureşti - Ilfov (Romania) is the fastest growing region in our sample during 2006-2015. Its actual growth rate per inhabitant is $7.97 \%$, but the model predicted growth is only $5.01 \%$. Such a high growth during the 9-year period is not a usual phenomenon, thus, it is considered rather a rare case than a recurrent event.

The difference between the actual economic growth and theoretically predicted growth per inhabitant does exist due to some unobserved economic factors. Nevertheless, the statistical development and data analysis tools have evolved over time, it is still impossible to catch all the determinants of economic growth. It is almost impossible to insert all the determinants in one model; hence, there will always be an unobserved factor. However, the authors' goal is not to target all the determinants, but rather the ones that affect the economic growth the most.

\section{LIMITATIONS AND SUGGESTIONS FOR FUTURE RESEARCH}

The authors were challenged to explain some of the previously developed determinants such as capital city effect or pentagon effect on economic growth. In fact, the inclusion of top 500 university ranking has not decreased significantly the posterior inclusions probability of the capital city effect. For further research, the authors suggest using universities that are located in capital cities only. These universities would directly influence the capital city variable and might explain the positive effect on economic growth from the capital city dummy variable. Due to the fact, that only part of best universities in the world is located in capital cities, it was enough to decrease the effect of capital city variable by $8.31 \%$. Hence, the idea that good education might stimulate economic growth has been observed in the model and also is in line with the literature. As for pentagon determinant, the authors have controlled for investments in industrial sector including the area inside pentagon. Nevertheless, the effect of a region being located in pentagon area has not been changed dramatically. Mostly, it comes from the fact that many corporates within the area of pentagon are outsourcing production stages. Hence, the authors faced a problem of omitted variable bias, and a deeper look shall be taken to explore additional potential determinants of a pentagon effect. 
Another limitation of the research is the data availability. Due to the fact that some regions either have not reported the data before 2006 or were not able to submit the statistics, regions with missing observations are not taken into account. Consequently, the authors decreased the dataset from 276 observations to 254 because of the data truncation. An alternative way for further research is determining growth determinants for NUTS 3 regions to increase the number of observations.

As for improvement, it might be beneficial for the article to check the SAR specification results using approach proposed by Cuaresma, Doppelhofer and Feldkircher (2009). They adjusted the weights to the distance between the regions using the equation 9:

$$
S_{i j}=d_{i j}{ }^{-\theta}
$$

where, $d_{i j}$ distance between region $i$ and region $j$, calculated based on the centroid of the regions and criterion $\theta$ shows the degree of the sensitivity of distance to the weight of the region. When $\theta$ is being equal to 1 , weight is completely inversely related to the distance between the regions, if the parameter is lower than one, a decay of weight declines, while an increase of $\theta$ will lead to a rise in the weight decay.

\section{CONCLUSION}

The article provides evidence of conditional beta-convergence among European NUTS2 regions, meaning that regions with a lower level of per capita income, controlling all the other factors, tend to grow faster than richer regions. The authors used post-crisis data to study the economic growth. The model explains about $70 \%$ of the economic growth per capita differences across the European regions. Furthermore, the authors found that the more people have only primary education in the region the lower is the economic growth. The authors also investigated other factors that depress the economy - high emission of $\mathrm{CO}_{2}$ and rapid population growth. In turn, regions which are located in pentagon area, shaped by London, Paris, Munich, Milan, and Hamburg, with a high share of information and communication technologies patents and a high share of industry in GVA have higher economic growth. One of the main findings of the article is that the authors present the empirical evidence that education quality positively contributes to economic growth when controlling for top 500 best schools in the world, thus, not only quantity of education, but also quality of education matters. Also, the authors determined the prime age population of the European NUTS2 regions. People aged 30-49 provide the largest added value to the economic development of the region. The larger the share of working population the more GDP per capita could potentially be created. Following the findings of Cuaresma (2009), the authors also provide the evidence that capital city regions tend to grow faster than other regions, keeping all other factors constant. Moreover, 
the economic growth is determined not only by internal factors but also by external factors - the neighbouring regions. The authors obtained that spatial effect appears to be significantly and positively contributing to economic growth. Hence, the rapid growth of neighbouring regions has a positive spillover effect on economic development of the regions.

The article indicates the importance of various economic growth determinants and the ease of implementation of each. As a result, this research might be helpful for regulators to correctly identify their policies and the direction of the structural reforms in order to ensure sustainable positive economic growth of the region and a country as a whole.

\section{REFERENCES}

Acemoglu, D., Johnson, S., \& Robinson, J. A. (2001). The Colonial Origins of Comparative Development: An Empirical Investigation, Vol. 91. (T. A. Review, Ed.) American Economic Association: American Economic Association.

Azariadis, C., Drazen, A. (1990). Threshold externalities in economic development. Quarterly Journal of Economics, 105(2), 501-526.

Barro, R. (1991). Economic growth in a cross section of countries. Quarterly Journal of Economics, 106(2), 407-443.

Barro, R., Lee, J.-W. (1994). Sources of economic growth. Carnegie-Rochester Conference Series on Public Policy, 40, 1-57.

Blazejowski, M., Gazda, J., Kwiatkowski, J. (2016). Bayesian Model Averaging in the Studies on Economic Growth in the EU Regions - Application of the gretl BMA package. Economics and Sociology, 9(4), 168-175.

Brock, W., Durlauf, S. (2001). Growth empirics and reality. World Bank Economic Review, 15(2), 229-272.

Caselli, F., Esquivel, G., Lefort, F. (1996). Reopening the Convergence Debate: A New Look at Cross-Country Growth Empirics. Journal of Economic Growth, 1(3), 363389.

Ciccone, A., \& Hall, E. R. (1996). Productivity and the Density of Economic Activity. The American Economic Review, Vol. 86, No. 1.

Cuaresma, J. C., Doppelhofer, G., Feldkircher, M. (2009). The determinants of economic growth in European regions. Regional Studies, 1-37.

Cuaresma, J. C., Foster, N., Stehrer, R. (2014). Determinants of Regional Economic Growth by Quantile. Regional Studies, 45(6), 809-826.

Danquah, M., Moral-Benito, E., Ouattara, B. (2014). TFP growth and its determinants: A model averaging approach. Empirical Economics, 227-251.

Danquah, M., Moral-Benito, M., \& Quattara, B. (2014). TFP growth and its determinants: a model averaging approach. Empirical Economics, 47(1), 227-251.

Deller, S. C., Lledo, V., Marcouiller, D. W. (2008). Modelling Regional Economic Growth With a Focus on Amenities. Review of Urban \& Regional Development Studies, 20(1), 1-21.

Ding, S., Knight, J. (2008). Why has China Grown so Fast? The Role of Structural Change. Department of Economics University of Oxford, 1-65.

Durlauf, S. N., Johnson, P. A., Temple J. R. W. (2005). Growth Econometrics. Handbook of Economic Growth. 
Easterly, W., \& Levine, R. (1997). Africa's Growth Tragedy: Policies and Ethnic Divisions. The Quarterly Journal of Economics, 112(4), 1203-1250.

Eicher, T., Papageorgiou, C., Roehn, O. (2007). Unraveling the Fortunes of the Fortunate: An Iterative Bayesian Model Averaging (IBMA) Approach. Journal of Macroeconomics, 29, 494-514.

Fang, X., Li, R., Kan, H., Bottai, M., Fang, F., \& Cao, Y. (2016). Bayesian model averaging method for evaluating associations between air pollution and respiratory mortality: a time-series study. BMJ Open, 6(8), e011487. Retrieved from http:// doi.org/10.1136/bmjopen-2016-011487

Fernandez, C., Ley, E., Steel, M. (2001). Model uncertainty in cross-country growth regressions. Journal of Applied Econometrics, 16(5), 563-576.

Forte A., Peiro-Palomino, J., Tortosa-Ausina, E. (2015). Does social capital matter for European regional growth? European Economic Review, 47-64.

Gomez, R., \& De Cos, P. H. (2008). Does Population Ageing Promote Faster Economic Growth? Review of Income and Wealth, 54, 350-372.

Grossman, G. M., Helpman, E. (1991). Quality Ladders in the Theory of Growth. The Review of Economic Studies, Vol. 58, No. 1., pp. 43-61.

Henderson, D., Russell, R. (2004). Human capital and convergence: A production frontier approach. International Economic Review.

Hongbin, L., et al. (2017). Human Capital and China's Future Growth.

Hoover, K., Perez, S. (2004). Truth and robustness in cross-country growth regressions. Oxford Bulletin of Economics and Statistics.

International Monetary Fund. (2010). Retrieved from imf.org: https://www.imf.org/ external/pubs/ft/weo $/ 2019 / 01 /$ weodata/weorept.aspx?pr. $\mathrm{x}=73 \&$ pr.y $=14 \&$ sy $=2$ $007 \&$ ey $=2010 \& \operatorname{scsm}=1 \& \mathrm{ssd}=1 \&$ sort $=$ country\&ds $=. \& \mathrm{br}=1 \& \mathrm{c}=941 \& \mathrm{~s}=\mathrm{NGDP}$ PC\%2CNID_NGDP\&grp $=0 \& a=$

Kaldewei, C. \& Walz, U. (2001). The Determinants of Regional Growth in Europe: An Empirical Investigation of Regional Growth Models.

Kelley, A. \& Schmidt, R. (1995). Aggregate population and economic growth correlations: The role of the components of demographic change. Demography, 32(4), 543-555.

Kass, R. E., Raftery, A. E. (1995). Bayes Factors. Journal of the American Statistical Association, (90), 773-795.

Kormendi, R., Meguire, P. (1985). Macroeconomic determinants of growth: Cross country evidence. Journal of Monetary Economics, 16(2), 141-163.

Lall, S., \& Yilmaz, S. (2000). Regional Economic Convergence: Do Policy Instruments Make a Difference? Washnigton: The International Bank for Reconstruction and Development/The World Bank.

Leamer (1983). Let's take the con out of econometrics. American Economic Review, 73(1), 31-43.

Ledyaeva, S. \& Linden, M. (2008). Determinants of Economic Growth: Empirical Evidence from Russian Regions. European Journal of Comparative Economics, 5(1), 87-105.

Leon-Gonzalez, R. and Montolio, D. (2004). Growth, convergence and public investment. Applied Economics, 1925-1936.

LeSage, J. P., Fischer, M. M. (2008). Spatial Growth Regressions: Model Specification. Spatial Economic Analysis, 3(3), 275-304.

Levine, R., Renelt, D. (1992). A sensitivity analysis of cross-country growth regressions. American Economic Review, 82(4), 942-963.

Ley, E., \& Steel, M. (2012). Mixtures of g-priors for Bayesian Model Averaging with Economic Applications. Journal of Econometric, 171, 251-266. 
Lichtenberg, F. R. (1992). R \& D Investment and International Productivity Differences. Economic Growth in the World Economy, Symposium 1992.

Lucas, R. (1988). On the mechanics of economic development. Journal of Monetary Economics, 22(1), 3-42.

Magrini Stefano. (1998). The determinants of regional growth: An empirical analysis. London, UK.

Mankiw, N. G., Romer, D., Weil, D. N. (1992). A contribution to the empirics of economic growth. Quarterly Journal of Economics, 107(2), 407-437.

Masanjala, W. H., Papageorgiou, C. (2008). Rough and lonely road to prosperity: a reexamination of the sources of growth in Africa using Bayesian model averaging. Journal of Applied Econometrics Vol. 23(5), 671-682.

Mehmet, N. \& B. Ulasan. (2013). Trade openness and economic growth: Bayesian model averaging estimate of cross-country growth regressions. Economic Modelling, Vol. 33, July 2013, pp. 867-883. Elsevier.

Polasek, W., Berrer, H. (2006). Traffic Sensitivity of Long-Term Regional Growth Forecasts. Institute for Advanced Studies, 220-243.

Polasek, W., Sellner, R. (2013). Does Globalization Affect Regional Growth? Evidence for NUTS-2 Regions in EU-27. Institute for Advanced Studies.

Pritchett, L. (1997). Divergence, big time. Journal of Economic Perspectives, 11(3), 3-17.

Próchniak, M. \& B. Witkowski. (2014). The application of Bayesian model averaging in assessing the impact of the regulatory framework on economic growth. Baltic Journal of Economics, 14(1-2), 159-180.

Raftery, A. (1995). Bayesian Model Selection in Social Research. Socialogical Methodo$\log y, 25,111-163$.

Rockey, J., Temple, J. (2016). Growth econometrics for agnostics and true believers. European Economic Review, 81(C), 86-102.

Romer, P. (1986). Increasing returns and long-run growth. Journal of Political Economy, 94(5), 1002-1037.

Sala-i-Martin, X. (1997). I just ran 2 million regressions. American Economic Review, $87(2), 178-183$.

Sala-i-Martin, X., Gernot, D., and R. I. Miller. (2004). Determinants of Long-Term Growth: A Bayesian Averaging of Classical Estimates (BACE) Approach. American Economic Review, 94(4), 813-835.

Sirimaneetham, V., Temple, J. R. W. (2009). Macroeconomic Stability and the Distribution of Growth Rates. World Bank.

Solow, R. (1956). A contribution to the theory of economic growth. Quarterly Journal of Economics, 70(1), 65-94.

Swan, T. (1956). Economic growth and capital accumulation. Economic Record, 32, 334-361.

Temple, J. (1999). The new growth evidence. Journal of Economic Literature, 37(1), 112 156.

Zeugner, S., \& Feldkircher, M. (2015). Bayesian Model Averaging Employing Fixed and Flexible Priors: The BMS Package for R. Journal of Statistical Software, 68(4), 1-37. 


\section{ApPENDices}

\section{Appendix A. Correlation matrix}

Table A.1

\section{Correlation matrix}

\begin{tabular}{|c|c|c|c|c|c|c|c|c|c|c|c|c|}
\hline & 壱 & 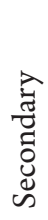 & 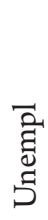 & 总 & 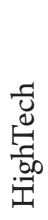 & Uِ & 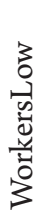 & 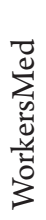 & $\frac{d^{\circ}}{\frac{e^{\prime}}{\pi^{3}}}$ & 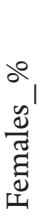 & 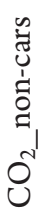 & 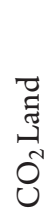 \\
\hline Primary & 요 & $\begin{array}{l}n \\
\infty \\
0 \\
1\end{array}$ & $\begin{array}{l}\infty \\
\circ \\
0 \\
\end{array}$ & ב- & $\stackrel{m}{\frac{m}{0}}$ & $\frac{N}{0}$ & ڤे & $\begin{array}{l}\sim \\
0 \\
0 \\
\end{array}$ & సै. & $\hat{\tilde{N}}$ & $\begin{array}{l}\text { ¿ } \\
0 \\
0\end{array}$ & $\begin{array}{l}n \\
0 \\
0 \\
1\end{array}$ \\
\hline Secondary & & \&. & $\stackrel{\square}{\circ}$ & $\begin{array}{l}\text { oे } \\
\text { ’ }\end{array}$ & $\overrightarrow{7}$ & 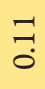 & $\begin{array}{l}\infty \\
\infty \\
\dot{0} \\
\dot{1}\end{array}$ & ڤ̆ & 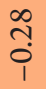 & 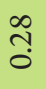 & $\stackrel{+}{\circ}$ & $\stackrel{\text { Oొ }}{0}$ \\
\hline Unemployment & & & $\stackrel{8}{8}$ & $\stackrel{n}{0}$ & $\begin{array}{l}\text { ț } \\
\dot{\varphi}\end{array}$ & $\begin{array}{l} \pm \\
\dot{0}\end{array}$ & $\begin{array}{l}\hat{O} \\
\dot{\varphi}\end{array}$ & $\stackrel{\circ}{\circ}$ & $\begin{array}{l}\text { பे } \\
\dot{0}\end{array}$ & $\stackrel{+}{\text { ப }}$ & $\stackrel{\infty}{\circ}$ & \& \\
\hline Employment & & & & هִ & $\begin{array}{l}\text { ț } \\
\dot{0}\end{array}$ & $\exists$ & $\begin{array}{l}\text { ọ } \\
\text { †े }\end{array}$ & $\begin{array}{l}\text { ○ } \\
\text { i }\end{array}$ & $\frac{\infty}{\dot{0}}$ & $\frac{\infty}{\dot{0}}$ & \& & $\stackrel{+}{0}$ \\
\hline HighTech & & & & & هִ & $\stackrel{+}{\stackrel{+}{0}}$ & $\frac{m}{\overrightarrow{0}}$ & 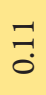 & $\begin{array}{l}0 \\
\stackrel{0}{0} \\
1\end{array}$ & $\begin{array}{l}0 \\
\stackrel{1}{0}\end{array}$ & $\begin{array}{l}0 \\
\text { Oे } \\
\text { i }\end{array}$ & F- \\
\hline ICT & & & & & & & 品 & $\overrightarrow{0}$ & 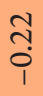 & กิ & $\begin{array}{l}\infty \\
\stackrel{0}{0} \\
\dot{1}\end{array}$ & $\begin{array}{l}\text { oे } \\
\text { i }\end{array}$ \\
\hline WorkersLow & & & & & & & هִ & $\begin{array}{l}0 \\
\infty \\
0 \\
i\end{array}$ & $\stackrel{\infty}{\stackrel{\infty}{0}}$ & $\begin{array}{l}\infty \\
\stackrel{1}{0} \\
\text { }\end{array}$ & $\begin{array}{l}\mathscr{0} \\
0 \\
0\end{array}$ & $\begin{array}{l}n \\
0 \\
0 \\
i\end{array}$ \\
\hline WorkersMed & & & & & & & & 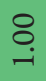 & $\begin{array}{l}\tilde{n} \\
\text { ọ }\end{array}$ & ֶึ & $\because$ & గి \\
\hline Males_\% & & & & & & & & & & $\underset{i}{\stackrel{8}{\circ}}$ & $\hat{\circ}$ & $\begin{array}{l}\infty \\
\stackrel{0}{0}\end{array}$ \\
\hline Females_\% & & & & & & & & & & نجه & $\begin{array}{l}\hat{0} \\
\dot{0}\end{array}$ & $\begin{array}{l}\infty \\
0 \\
0\end{array}$ \\
\hline $\mathrm{CO}_{2}$ non-cars & & & & & & & & & & & & $\underset{-}{8}$ \\
\hline $\mathrm{CO}_{2}$ land & & & & & & & & & & & & $\underset{-}{8}$ \\
\hline
\end{tabular}

Note. Table created by the authors using the data described in the Data section and correlation function in Microsoft Excel 2016. 
Appendix B. BMA regression: Explanation of Pentagon's Significance Level

Table B.1

BMA regression: Explanation of Pentagon's significance level with Industry GVA

\begin{tabular}{|l|c|c|c|c|}
\hline & PIP & $\begin{array}{c}\text { Posterior } \\
\text { Mean }\end{array}$ & Posterior SD & $\begin{array}{c}\text { Conditional } \\
\text { Sign }\end{array}$ \\
\hline Nat_Income PPP per inh & 0.9999 & -0.0000 & 0.0000 & 0 \\
Pentagon & 0.9843 & 0.0093 & 0.0030 & 1 \\
Investments & 0.9119 & 0.0590 & 0.0284 & 1 \\
Population growth & 0.8786 & -0.5110 & 0.2799 & 0 \\
\hline
\end{tabular}

\begin{tabular}{|l|c|c|c|c|}
\hline & PIP & $\begin{array}{c}\text { Posterior } \\
\text { Mean }\end{array}$ & Posterior SD & $\begin{array}{c}\text { Conditional } \\
\text { Sign }\end{array}$ \\
\hline Industry GVA & 0.9999 & 0.0711 & 0.0127 & 1 \\
Pentagon & 0.9999 & -0.0000 & 0.0000 & 0 \\
Nat_Income PPP per inh & 0.8722 & 0.0065 & 0.0034 & 1 \\
Investments & 0.4182 & 0.0163 & 0.0239 & 1 \\
Population growth & 0.2541 & -0.0603 & 0.1522 & 0 \\
\hline
\end{tabular}

Note. Table created by the authors using the data described in the Data section and RStudio software. 


\section{Appendix C. Predictions of regional GDP per capita GROWTH (2006-2015)}

\begin{tabular}{|c|c|c|c|c|c|c|c|c|c|}
\hline $\mathrm{Nr}$ & Region & Reality & Prediction & $\mathrm{Nr}$ & Region & Reality & rediction & $\mathrm{Nr}$ & Region \\
\hline 1 & Sterea Ellada & $-2.20 \%$ & $0.49 \%$ & 61 & Highlands and Islands & $1.04 \%$ & $1.85 \%$ & 121 & Mellersta Norrland \\
\hline 2 & Ionia Nisia & $-1.63 \%$ & $-0.51 \%$ & 62 & Greater Manchester & $1.07 \%$ & $1.04 \%$ & 122 & Surrey, East and West Su \\
\hline 3 & Kriti & $-1.37 \%$ & $0.25 \%$ & 63 & Eastern Scotland & $1.08 \%$ & $2.09 \%$ & 123 & Länsi-Suomi \\
\hline 4 & Dytiki Ellada & $-1.34 \%$ & $0.23 \%$ & 64 & Dorset and Somerset & $1.08 \%$ & $0.76 \%$ & 124 & País Vasco \\
\hline 5 & Anatoliki Makedonia, T & $-1.23 \%$ & $0.53 \%$ & 65 & Comunidad Foral de $\mathrm{Na}$ & $1.08 \%$ & $1.46 \%$ & 125 & Galicia \\
\hline 6 & Ipeiros & $-1.20 \%$ & $-0.47 \%$ & 66 & Principado de Asturias & $1.10 \%$ & $1.32 \%$ & 126 & Darmstadt \\
\hline 7 & Kentriki Makedonia & $-1.10 \%$ & $0.81 \%$ & 67 & Puglia & $1.11 \%$ & $0.55 \%$ & 127 & Helsinki-Uusimaa \\
\hline 8 & Notio Aigaio & $-1.02 \%$ & $0.70 \%$ & 68 & Lombardia & $1.11 \%$ & $0.99 \%$ & 128 & Herefordshire, Worcest \\
\hline 9 & Thessalia & $-1.00 \%$ & $0.10 \%$ & 69 & Bretagne & $1.12 \%$ & $1.88 \%$ & 129 & Friesland (NL) \\
\hline 10 & Voreio Aigaio & $-0.97 \%$ & $-0.11 \%$ & 70 & Northumberland and $\mathrm{Ty}$ & $1.12 \%$ & $0.62 \%$ & 130 & Prov. Hainaut \\
\hline 11 & Dytiki Makedonia & $-0.80 \%$ & $1.05 \%$ & 71 & Algarve & $1.12 \%$ & $-0.36 \%$ & 131 & Gelderland \\
\hline 12 & Border, Midland and W & $-0.65 \%$ & $1.47 \%$ & 72 & Essex & $1.12 \%$ & $1.23 \%$ & 132 & Groningen \\
\hline 13 & Peloponnisos & $-0.56 \%$ & $0.27 \%$ & 73 & Basse-Normandie & $1.13 \%$ & $1.56 \%$ & 133 & Overijssel \\
\hline 14 & Attiki & $-0.45 \%$ & $1.72 \%$ & 74 & Cataluña & $1.15 \%$ & $1.14 \%$ & 134 & Nord - Pas-de-Calais \\
\hline 15 & Ciudad Autónoma de M & $-0.44 \%$ & $0.88 \%$ & 75 & Liguria & $1.17 \%$ & $0.49 \%$ & 135 & Abruzzo \\
\hline 16 & Toscana & $0.00 \%$ & $0.31 \%$ & 76 & Leicestershire, Rutland a & $1.19 \%$ & $1.16 \%$ & 136 & Prov. Antwerpen \\
\hline 17 & Umbria & $0.00 \%$ & $0.96 \%$ & 77 & Languedoc-Roussillon & $1.20 \%$ & $0.62 \%$ & 137 & Sydsverige \\
\hline 18 & Marche & $0.00 \%$ & $0.48 \%$ & 78 & Zuid-Holland & $1.20 \%$ & $1.57 \%$ & 138 & Prov. Namur \\
\hline 19 & Lazio & $0.00 \%$ & $0.87 \%$ & 79 & Provincia Autonoma di & $1.20 \%$ & $1.27 \%$ & 139 & Prov. Liège \\
\hline 20 & Lisboa & $0.00 \%$ & $0.04 \%$ & 80 & Castilla y León & $1.22 \%$ & $1.03 \%$ & 140 & Noord-Holland \\
\hline 21 & Pohjois- ja Itä-Suomi & $0.00 \%$ & $2.46 \%$ & 81 & Nord-Est & $1.22 \%$ & $2.92 \%$ & 141 & Noord-Brabant \\
\hline 22 & Canarias & $0.03 \%$ & $1.21 \%$ & 82 & La Rioja & $1.22 \%$ & $1.40 \%$ & 142 & Corse \\
\hline 23 & Kú $\pi \rho \circ$ (Kýpros) & $0.08 \%$ & $0.66 \%$ & 83 & Drenthe & $1.22 \%$ & $2.47 \%$ & 143 & Limburg (NL) \\
\hline 24 & Molise & $0.31 \%$ & $0.87 \%$ & 84 & Etelä-Suomi & $1.23 \%$ & $2.47 \%$ & 144 & Cheshire \\
\hline 25 & Illes Balears & $0.42 \%$ & $0.65 \%$ & 85 & Haute-Normandie & $1.23 \%$ & $1.08 \%$ & 145 & Gießen \\
\hline 26 & Campania & $0.45 \%$ & $0.37 \%$ & 86 & Åland & $1.24 \%$ & $1.13 \%$ & 146 & Norte \\
\hline 27 & Sicilia & $0.46 \%$ & $1.07 \%$ & 87 & Derbyshire and Notting & $1.25 \%$ & $1.21 \%$ & 147 & Schleswig-Holstein \\
\hline 28 & Ciudad Autónoma de C & $0.46 \%$ & $0.10 \%$ & 88 & South Western Scotland & $1.26 \%$ & $1.20 \%$ & 148 & Östra Mellansverige \\
\hline 29 & Northern Ireland & $0.50 \%$ & $1.54 \%$ & 89 & Prov. Luxembourg (BE) & $1.27 \%$ & $1.37 \%$ & 149 & Bremen \\
\hline 30 & East Yorkshire and Nor & $0.57 \%$ & $1.45 \%$ & 90 & Wien & $1.29 \%$ & $2.11 \%$ & 150 & Köln \\
\hline 31 & Andalucía & $0.57 \%$ & $1.17 \%$ & 91 & Aragón & $1.29 \%$ & $1.40 \%$ & 151 & Stockholm \\
\hline 32 & Shropshire and Stafford & $0.59 \%$ & $0.90 \%$ & 92 & Aquitaine & $1.29 \%$ & $0.89 \%$ & 152 & Zeeland \\
\hline 33 & Bedfordshire and Hertf & $0.60 \%$ & $1.28 \%$ & 93 & Alentejo & $1.31 \%$ & $0.12 \%$ & 153 & Hannover \\
\hline 34 & Région de Bruxelles-Ca & $0.60 \%$ & $1.50 \%$ & 94 & Emilia-Romagna & $1.32 \%$ & $0.80 \%$ & 154 & Övre Norrland \\
\hline 35 & Cantabria & $0.67 \%$ & $1.26 \%$ & 95 & Tees Valley and Durham & $1.32 \%$ & $1.49 \%$ & 155 & Düsseldorf \\
\hline 36 & Castilla-La Mancha & $0.71 \%$ & $0.85 \%$ & 96 & West Wales and The Vall & $1.33 \%$ & $1.00 \%$ & 156 & Provincia Autonoma di \\
\hline 37 & Piemonte & $0.71 \%$ & $1.08 \%$ & 97 & Extremadura & $1.34 \%$ & $0.70 \%$ & 157 & Kärnten \\
\hline 38 & Cornwall and Isles of S & $0.71 \%$ & $1.24 \%$ & 98 & Merseyside & $1.34 \%$ & $1.01 \%$ & 158 & Småland med öarna \\
\hline 39 & East Wales & $0.72 \%$ & $1.42 \%$ & 99 & Auvergne & $1.35 \%$ & $0.89 \%$ & 159 & Severozápad \\
\hline 40 & Valle d'Aosta/Vallée d'A & $0.72 \%$ & $1.00 \%$ & 100 & Utrecht & $1.35 \%$ & $1.67 \%$ & 160 & Prov. West-Vlaanderen \\
\hline 41 & Franche-Comté & $0.73 \%$ & $1.61 \%$ & 101 & Hampshire and Isle of W & $1.37 \%$ & $1.81 \%$ & 161 & Prov. Oost-Vlaanderen \\
\hline 42 & Comunidad Valenciana & $0.73 \%$ & $1.09 \%$ & 102 & Bourgogne & $1.39 \%$ & $1.14 \%$ & 162 & Steiermark \\
\hline 43 & Región de Murcia & $0.74 \%$ & $1.18 \%$ & 103 & Comunidad de Madrid & $1.41 \%$ & $1.73 \%$ & 163 & Prov. Limburg (BE) \\
\hline 44 & Região Autónoma da M. & $0.77 \%$ & $1.36 \%$ & 104 & Flevoland & $1.42 \%$ & $2.48 \%$ & 164 & Västsverige \\
\hline 45 & Devon & $0.80 \%$ & $1.09 \%$ & 105 & Provence-Alpes-Côte & $1.44 \%$ & $0.66 \%$ & 165 & Île de France \\
\hline 46 & Champagne-Ardenne & $0.81 \%$ & $1.42 \%$ & 106 & Gloucestershire, Wiltshi & $1.47 \%$ & $1.41 \%$ & 166 & Tirol \\
\hline 47 & Lorraine & $0.81 \%$ & $1.86 \%$ & 107 & Região Autónoma dos A & $1.47 \%$ & $-0.70 \%$ & 167 & Trier \\
\hline 48 & Limousin & $0.82 \%$ & $0.54 \%$ & 108 & Alsace & $1.49 \%$ & $2.07 \%$ & 168 & Prov. Vlaams-Brabant \\
\hline 49 & North Yorkshire & $0.82 \%$ & $0.43 \%$ & 109 & Berkshire, Buckinghams & $1.50 \%$ & $1.66 \%$ & 169 & Niederösterreich \\
\hline 50 & Sardegna & $0.83 \%$ & $1.10 \%$ & 110 & Pays de la Loire & $1.51 \%$ & $0.87 \%$ & 170 & Karlsruhe \\
\hline 51 & West Midlands & $0.84 \%$ & $0.76 \%$ & 111 & Basilicata & $1.52 \%$ & $1.52 \%$ & 171 & Oberbayern \\
\hline 52 & South Yorkshire & $0.87 \%$ & $1.33 \%$ & 112 & Lincolnshire & $1.52 \%$ & $0.46 \%$ & 172 & Münster \\
\hline 53 & Calabria & $0.90 \%$ & $0.84 \%$ & 113 & Rhône-Alpes & $1.54 \%$ & $1.32 \%$ & 173 & Saarland \\
\hline 54 & Kent & $0.91 \%$ & $1.25 \%$ & 114 & Midi-Pyrénées & $1.54 \%$ & $1.61 \%$ & 174 & Dél-Dunántúl \\
\hline 55 & Centre & $0.93 \%$ & $1.39 \%$ & 115 & Poitou-Charentes & $1.57 \%$ & $0.61 \%$ & 175 & Oberösterreich \\
\hline 56 & 6 West Yorkshire & $0.95 \%$ & $1.11 \%$ & 116 & East Anglia & $1.57 \%$ & $1.83 \%$ & 176 & Közép-Magyarország \\
\hline 57 & Friuli-Venezia Giulia & $0.95 \%$ & $0.76 \%$ & 117 & Centro (PT) & $1.58 \%$ & $-0.15 \%$ & 177 & Prov. Brabant Wallon \\
\hline 58 & Picardie & $0.97 \%$ & $1.09 \%$ & 118 & Southern and Eastern & $1.59 \%$ & $1.74 \%$ & 178 & Vorarlberg \\
\hline 59 & Veneto & $0.99 \%$ & $1.10 \%$ & 119 & Hamburg & $1.61 \%$ & $1.81 \%$ & 179 & Lüneburg \\
\hline 60 & Lancashire & $1.01 \%$ & $1.30 \%$ & 120 & Norra Mellansverige & $1.66 \%$ & $1.35 \%$ & 180 & Severozapaden \\
\hline
\end{tabular}




\begin{tabular}{|c|c|c|c|c|c|c|c|c|c|}
\hline Reality & ediction & $\mathrm{Nr}$ & Region & Reality & ediction & $\mathrm{Nr}$ & \begin{tabular}{l|l} 
Region \\
\end{tabular} & Reality & ediction \\
\hline $1.68 \%$ & $0.98 \%$ & 181 & Arnsberg & $2.70 \%$ & $2.28 \%$ & 241 & Wielkopolskie & $5.43 \%$ & $4.08 \%$ \\
\hline $1.70 \%$ & $1.42 \%$ & 182 & Kassel & $2.70 \%$ & $2.42 \%$ & 242 & Małopolskie & $5.46 \%$ & $3.98 \%$ \\
\hline $1.71 \%$ & $2.05 \%$ & 183 & Praha & $2.70 \%$ & $3.03 \%$ & 243 & Łódzkie & $5.48 \%$ & $3.89 \%$ \\
\hline $1.71 \%$ & $1.82 \%$ & 184 & Jihozápad & $2.73 \%$ & $3.88 \%$ & 244 & Yugozapaden & $5.68 \%$ & $5.04 \%$ \\
\hline $1.72 \%$ & $1.22 \%$ & 185 & Koblenz & $2.76 \%$ & $1.81 \%$ & 245 & Mazowieckie & $5.71 \%$ & $3.65 \%$ \\
\hline $1.73 \%$ & $1.87 \%$ & 186 & Salzburg & $2.77 \%$ & $1.93 \%$ & 246 & Lietuva & $6.14 \%$ & $5.73 \%$ \\
\hline $1.74 \%$ & $2.53 \%$ & 187 & Detmold & $2.79 \%$ & $2.53 \%$ & 247 & Dolnośląskie & $6.21 \%$ & $4.39 \%$ \\
\hline $1.74 \%$ & $0.62 \%$ & 188 & Rheinhessen- & $2.80 \%$ & $2.49 \%$ & 248 & Sud-Vest Oltenia & $6.49 \%$ & $5.05 \%$ \\
\hline $1.74 \%$ & $2.25 \%$ & 189 & Burgenland (A) & $2.82 \%$ & $2.10 \%$ & 249 & Vest & $6.54 \%$ & $5.36 \%$ \\
\hline $1.79 \%$ & $1.60 \%$ & 190 & Unterfranken & $2.83 \%$ & $2.33 \%$ & 250 & Nord-Vest & $6.66 \%$ & $4.43 \%$ \\
\hline $1.80 \%$ & $1.78 \%$ & 191 & Berlin & $2.83 \%$ & $2.84 \%$ & 251 & Centru & $6.77 \%$ & $4.68 \%$ \\
\hline $1.80 \%$ & $3.74 \%$ & 192 & Freiburg & $2.86 \%$ & $3.03 \%$ & 252 & Sud - Muntenia & $7.44 \%$ & $5.53 \%$ \\
\hline $1.80 \%$ & $2.16 \%$ & 193 & Dresden & $2.89 \%$ & $3.21 \%$ & 253 & Sud-Est & $7.62 \%$ & $4.83 \%$ \\
\hline $1.81 \%$ & $1.34 \%$ & 194 & Severovýchod & $2.93 \%$ & $4.07 \%$ & 254 & Bucureşti - Ilfov & $7.97 \%$ & $5.01 \%$ \\
\hline $1.81 \%$ & $0.89 \%$ & 195 & Weser-Ems & $2.96 \%$ & $2.82 \%$ & & & & \\
\hline $1.82 \%$ & $2.04 \%$ & 196 & Mittelfranken & $2.97 \%$ & $2.52 \%$ & & & & \\
\hline $1.84 \%$ & $1.15 \%$ & 197 & Schwaben & $2.98 \%$ & $2.63 \%$ & & & & \\
\hline $1.86 \%$ & $1.28 \%$ & 198 & Sachsen-Anhs & $3.00 \%$ & $3.52 \%$ & & & & \\
\hline $1.86 \%$ & $1.42 \%$ & 199 & Észak-Alföld & $3.03 \%$ & $3.86 \%$ & & & & \\
\hline $1.90 \%$ & $2.14 \%$ & 200 & Moravskoslez & $3.08 \%$ & $4.44 \%$ & & & & \\
\hline $1.93 \%$ & $2.82 \%$ & 201 & Mecklenburg- & $3.12 \%$ & $2.56 \%$ & & & & \\
\hline $2.01 \%$ & $0.37 \%$ & 202 & Tübingen & $3.13 \%$ & $2.80 \%$ & & & & \\
\hline $2.01 \%$ & $2.33 \%$ & 203 & Közép-Dunán & $3.18 \%$ & $4.62 \%$ & & & & \\
\hline $2.09 \%$ & $0.58 \%$ & 204 & Észak-Magyan & $3.19 \%$ & $4.46 \%$ & & & & \\
\hline $2.12 \%$ & $2.59 \%$ & 205 & Brandenburg & $3.23 \%$ & $2.88 \%$ & & & & \\
\hline $2.15 \%$ & $0.59 \%$ & 206 & Střední Čechy & $3.27 \%$ & $3.86 \%$ & & & & \\
\hline $2.15 \%$ & $1.95 \%$ & 207 & Stuttgart & $3.28 \%$ & $2.40 \%$ & & & & \\
\hline $2.16 \%$ & $1.59 \%$ & 208 & Niederbayern & $3.32 \%$ & $3.24 \%$ & & & & \\
\hline $2.23 \%$ & $2.45 \%$ & 209 & Cumbria & $3.38 \%$ & $1.25 \%$ & & & & \\
\hline $2.27 \%$ & $2.36 \%$ & 210 & Dél-Alföld & $3.42 \%$ & $3.88 \%$ & & & & \\
\hline $2.29 \%$ & $2.26 \%$ & 211 & Yugoiztochen & $3.44 \%$ & $5.65 \%$ & & & & \\
\hline $2.30 \%$ & $1.97 \%$ & 212 & Oberfranken & $3.45 \%$ & $2.57 \%$ & & & & \\
\hline $2.33 \%$ & $2.81 \%$ & 213 & Braunschweig & $3.52 \%$ & $3.53 \%$ & & & & \\
\hline $2.33 \%$ & $1.95 \%$ & 214 & Thüringen & $3.52 \%$ & $3.58 \%$ & & & & \\
\hline $2.33 \%$ & $1.76 \%$ & 215 & Malta & $3.62 \%$ & $1.08 \%$ & & & & \\
\hline $2.33 \%$ & $0.30 \%$ & 216 & Severen tsentr & $3.63 \%$ & $4.21 \%$ & & & & \\
\hline $2.33 \%$ & $2.59 \%$ & 217 & Oberpfalz & $3.64 \%$ & $3.16 \%$ & & & & \\
\hline $2.34 \%$ & $0.85 \%$ & 218 & North Eastern & $3.70 \%$ & $1.64 \%$ & & & & \\
\hline $2.40 \%$ & $4.24 \%$ & 219 & Yuzhen tsentra & $3.75 \%$ & $5.03 \%$ & & & & \\
\hline $2.41 \%$ & $1.26 \%$ & 220 & Jihovýchod & $3.85 \%$ & $4.12 \%$ & & & & \\
\hline $2.41 \%$ & $1.87 \%$ & 221 & Střední Morar & $3.91 \%$ & $4.51 \%$ & & & & \\
\hline $2.42 \%$ & $2.67 \%$ & 222 & Severoiztoche & $4.24 \%$ & $3.81 \%$ & & & & \\
\hline $2.42 \%$ & $2.56 \%$ & 223 & Nyugat-Dunál & $4.31 \%$ & $4.56 \%$ & & & & \\
\hline $2.47 \%$ & $1.40 \%$ & 224 & Lubuskie & $4.47 \%$ & $5.19 \%$ & & & & \\
\hline $2.47 \%$ & $1.90 \%$ & 225 & Východné Slo & $4.60 \%$ & $4.51 \%$ & & & & \\
\hline $2.47 \%$ & $2.61 \%$ & 226 & Západné Slov & $4.65 \%$ & $5.21 \%$ & & & & \\
\hline $2.49 \%$ & $2.27 \%$ & 227 & Zachodniopor & $4.67 \%$ & $3.59 \%$ & & & & \\
\hline $2.51 \%$ & $1.21 \%$ & 228 & Świętokrzyski & $4.71 \%$ & $3.69 \%$ & & & & \\
\hline $2.52 \%$ & $1.90 \%$ & 229 & Kujawsko-Po & $4.71 \%$ & $4.68 \%$ & & & & \\
\hline $2.52 \%$ & $2.72 \%$ & 230 & Eesti & $4.72 \%$ & $4.77 \%$ & & & & \\
\hline $2.53 \%$ & $2.39 \%$ & 231 & Warmińsko- $\mathrm{N}$ & $4.74 \%$ & $4.28 \%$ & & & & \\
\hline $2.57 \%$ & $2.52 \%$ & 232 & Bratislavský k & $4.78 \%$ & $3.76 \%$ & & & & \\
\hline $2.59 \%$ & $2.83 \%$ & 233 & Latvija & $5.00 \%$ & $4.94 \%$ & & & & \\
\hline $2.60 \%$ & $3.79 \%$ & 234 & Podlaskie & $5.00 \%$ & $4.84 \%$ & & & & \\
\hline $2.60 \%$ & $2.01 \%$ & 235 & Śląskie & $5.00 \%$ & $4.78 \%$ & & & & \\
\hline $2.63 \%$ & $3.33 \%$ & 236 & Pomorskie & $5.01 \%$ & $4.12 \%$ & & & & \\
\hline $2.65 \%$ & $1.65 \%$ & 237 & Opolskie & $5.09 \%$ & $5.28 \%$ & & & & \\
\hline $2.65 \%$ & $2.42 \%$ & 238 & Lubelskie & $5.13 \%$ & $3.88 \%$ & & & & \\
\hline $2.68 \%$ & $2.13 \%$ & 239 & Podkarpackie & $5.15 \%$ & $4.73 \%$ & & & & \\
\hline $2.70 \%$ & $5.64 \%$ & 240 & Stredné Slove & $5.20 \%$ & $4.68 \%$ & & & & \\
\hline
\end{tabular}

